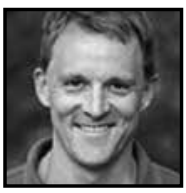

\title{
Beginning Science Teachers' Use of Tools to Learn Ambitious Instruction
}

\author{
David Stroupe, Michigan State University
}

\begin{abstract}
A lack of coherence about norms for instruction between preparation contexts often results in tensions for beginners about learning to teach. I wondered if planning tools created in a university setting, designed to support ambitious instruction, could act as boundary objects to help novices bring ambitious teaching into classrooms. As such, I examined how three participants used the tools to plan for ambitious instruction in ways that changed their own understanding of subject matter and pedagogy. Their mentor teachers, however, prompted the novices to use the tools and teach in ways that were inconsistent with the participants' planning. I found that the tools prompted the novices to try out pieces of ambitious instruction, yet the tools alone do not encourage coherence or communication between beginning and mentor teachers.
\end{abstract}

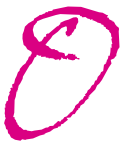

ne challenge facing science teacher preparation is the lack of consensus about what constitutes instructional excellence. Along with colleagues, I propose that a growing movement to characterize rigorous and equitable teaching as "ambitious instruction" in other subject matter areas, such as mathematics and literacy education, can serve as a guide for the science education community to develop a vision of effective classroom pedagogy. Ambitious instruction supports students of all ethnic, racial, class, ability, and gender categories to participate in the conceptual, epistemic, social, and material processes of a discipline (Ball, Sleep, Boerst, \& Bass, 2009; Duschl, 2008; Kazemi, Franke, \& Lampert, 2009; Lampert \& Graziani, 2009; Windschitl, Thompson, Braaten, \& Stroupe, 2012). A key feature of ambitious instruction is that student thinking plays a central role in teachers' daily work. Teachers plan, instruct in the moment, and reflect while constantly considering how to adapt instruction to work on 
and with students' ideas (see Warren, Ballenger, Ogonowski, Rosebery, \& HudicourtBarnes, 2001; Warren \& Rosebery, 1995).

\section{Supporting Ambitious Instruction Across Contexts Using Tools}

Supporting beginning teachers' learning and enactment of ambitious instruction is complicated, because their preparation trajectory extends across a variety of contexts, including teacher education courses, early field experiences in schools, and internships (Cobb, Zhao, \& Dean, 2009; Grossman, Hammerness, \& McDonald, 2009; Zeichner, 2010). In each setting, beginning teachers interact with other people, with materials, and historical/institutional expectations about how teaching and learning can unfold (Sykes, Bird, \& Kennedy, 2010). However, rarely do settings share a common vision of teaching to act as reliable anchors for supporting beginning teacher learning (Kennedy, 2010; Putnam \& Borko, 2000; Sykes et al., 2010). Novices, therefore, experience tensions when learning to teach as they try to make sense of competing messages about "what counts" as competent instruction in these varied contexts (Gainsburg, 2012; Grossman \& McDonald, 2008; Wilson \& Berne, 1999; Zeichner, 2010).

To better understand how novices negotiate these contexts, I investigated how a suite of planning tools, used by preservice teachers to plan for ambitious instruction, could act as boundary objects as the beginning teachers moved from a secondary science methods class to student teaching. By boundary objects, I mean that the tools could facilitate interconnections between contexts as people familiar with ambitious instruction (the student teachers) and those who frame teaching as the delivery of information (mentor teachers, in this instance, all described teaching as transmitting information to students). I hoped that the tools might act as a "nexus of perspectives" (Wenger, 1998), connecting novices and mentor teachers as they worked together to support student learning through the design of ambitious instruction. Specifically, I asked:

1) How do beginning teachers use planning tools, which promote ambitious instruction, in a school context that frames instruction as "information delivery"?

2) How and why do preservice teachers' attempts at ambitious instruction, planned using the tools, evolve in schools that advocate for "information delivery"?

The role and structure of planning tools. The planning tools press beginning teachers to construct a "big idea"-framed unit. By "big ideas," I mean substantive relationships between concepts in the form of scientific models that help learners 
understand, explain, and predict a variety of important phenomena in the natural world (Windschitl et al., 2012). Teachers constructing a big idea-framed unit with the planning tools "unpack" a science topic, and "repack" the topic as an inquiry-worthy idea to build a unit around (Penuel \& Gallagher, 2009). For example, if the curriculum lists tangible entities as the topic (e.g., batteries and bulbs, acids and bases, plants, types of rocks), the teacher could reason: "Should details and facts about these 'things' be the target of study, or are there more fundamental processes associated with these that children should understand?" "Are these things worth studying because they are part of a larger system of activity?" and "What aspects of these things might be relevant to childrens' lives?"

Using planning tools to construct a big idea-framed unit is a critical pre-condition to enacting ambitious teaching. For example, Thompson, Windschitl, and Braaten (2013) found that only beginners who reconceptualized curriculum topics as a big idea using the planning tools attempted some form of ambitious teaching during the course of a unit. Whereas, novices who did not construct big ideas felt obligated to take mundane curricular topics (e.g., "glaciers," "sound," "solutions") at face value and not seek deeper or more comprehensive scientific ideas that could help students make sense of the many activities prescribed in the support materials. Such teachers also adhered to their activity-centered curricula, or merely altered minor lesson details.

The initial work of constructing a big idea-framed unit using the planning tools requires novices to develop an explicit and elaborate understanding of the target ideas they are to teach, as well as a trajectory of sense-making activities to frame the unit. The tools are purposely low-tech, consisting of an electronic document in which participants can type in responses to a series of prompts, and that can be revised as new ideas come to light (see Figure 1 for a sample page from a tool). The planning tools also discouraged the notion that a big idea could be captured in a single word or phrase like "heredity," "force and motion," or "volcanoes." Instead, they portrayed big ideas as relationships between some natural phenomenon and its underlying causal explanation. In addition, the tools scaffolded the kinds of thinking that ambitious teachers engage in when trying to locate and re-package fundamental ideas of importance within common curriculum topics-ideas that are actionable in terms of designing instruction.

Preservice teachers' pedagogical reasoning with tools. The planning tools also required that participants engage in four pedagogical reasoning processes-recasting the big idea, replaying the lesson while paying attention to students' ideas, considering alternative plans given a different set of teaching circumstances, and projecting their pedagogical ideas and content knowledge into an imagined future practice. 
One reasoning process, recasting the big idea, occurred as participants constantly revisited and interrogated their own content knowledge as they learned more about their students' emerging science ideas. They then used their evolving content knowledge, planning tools, and students' emerging science ideas to reconsider the big idea. As participants recast their big idea, they engaged in a related pedagogical reasoning process while using the planning tools-replaying a lesson (Horn, 2010). As participants replayed a lesson, they evaluated the effectiveness of specific instructional moves, considered the state of students' emerging science ideas, and made instructional decisions in conjunction with recasting the big idea. In turn, this enabled the participants to make sense of their current classroom realities in relation to their own ambitious vision of practice. These processes had a discernable and immediate impact on practice, and resulted in immediate changes to the units.

At the same time, participants also used the planning tools as resources to reason about how they would enact the "big idea" planning practice in imagined contexts. One such pedagogical reasoning process, alternative reasoning, was the participants' opportunity to consider how they would plan and teach their unit to their current students given a different set of contextual affordances and constraints. This reasoning process often began with the phrase, "If I had more time, I would..." or "If I could teach this the way I wanted to, I would..." Alternative reasoning highlighted what the participants learned about students' emerging science ideas and considered important to teach in response to students' intellectual and pedagogical needs, but were unable to do so because of contextual constraints.

In addition to alternative reasoning, participants engaged in projective reasoning. Such reasoning enabled the participants to imagine how they might teach their unit differently in some future context. This reasoning was indicated by participants stating, "Next time I teach this I will..." and "For future classes, I will..." Projective reasoning showed the participants' learning by illustrating what elements of practice they considered important enough to try again. Alternative and projective reasoning processes, while not providing immediate assistance to practice, like recasting and replaying, enabled the participants to refine their ambitious vision by allowing them to imagine teaching their actual students and future students, under a different set of affordances and constraints.

I hypothesized that unpacking the big idea with the planning tools would help participants construct learning goals, in terms of both concepts and performances, that would go beyond what is expected of students in most curricula. I further hypothesized that, for teachers using the planning tools, to reason with and about their subject 
matter and pedagogical knowledge would serve a priming function. By priming, I mean that in the process of planning, teachers explicitly surface the important pieces of the causal explanation, and identify the ideas and language that students might draw upon to make sense of this science work. Priming, I thought, could prepare teachers for classroom discourse and enable them to recognize important threads of partial understandings in students' talk. In other words, I thought the tools could expand the range of what novices recognize as student contributions, and that could be built upon or challenged in particular ways, rather than dismissed as irrelevant.

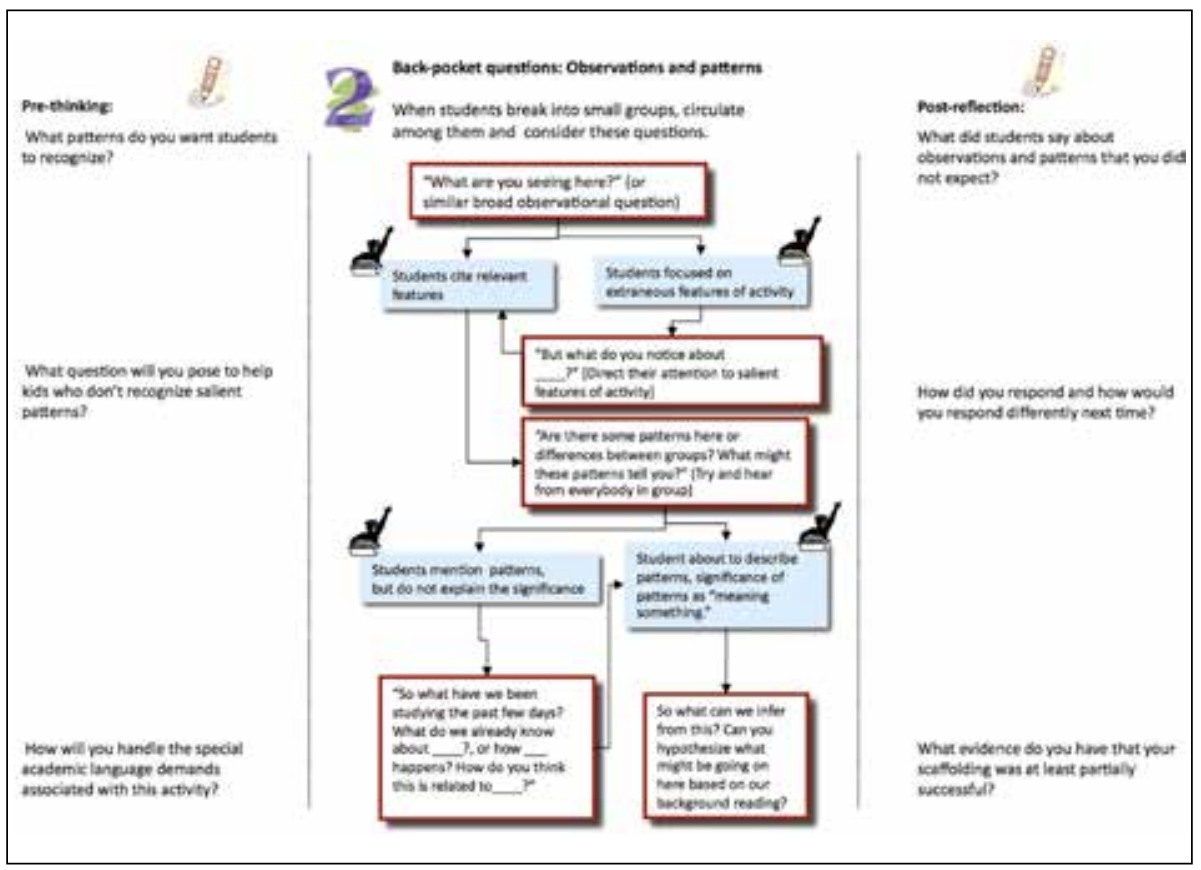

Fig. 1: Sample page from planning tool

\section{Three Preservice Teachers' Stories}

I now present the stories of three preservice teachers' learning as they attempted to use planning tools to enact big idea-framed units in schools where such instruction was questioned. The three participants, Katie, Robert, and Amber (each name is a pseudonym) hold a bachelor's degree in a science field and were all students in the secondary science methods course that I co-taught. My data collection occurred during a two-week time period in which the participants acted as the primary instructor in their internship classrooms for the first time. As such, they were responsible for planning, teaching, and assessing student learning. In each story, I describe how the teacher 
candidates used the planning tools not only to plan for effective instruction, but also to later reason about students' ideas in ways that changed their own understanding of both subject matter and pedagogy. Their mentor teachers, however, prompted the novices to teach in ways that were inconsistent with what they planned for using the tools. The tensions that arose between the novice and mentor teachers around the planning tools resulted in each participant compromising their actual instruction to some degree, which runs counter to a common belief that teachers' instruction over the course of a unit results from a linear progression of decisions, beginning with content knowledge informing reasoning, which teachers then subsequently translate into practice.

Katie's unit. Katie's mentor teacher assigned her to teach about volcanoes. Concerned about her inexperience with earth science since she held a biology degree, Katie relied extensively on her mentor teacher's volcano lessons from previous years to inform her big idea construction and unit planning. Though supportive of her as a preservice teacher, Katie's mentor expressed concern that her "style" of lessons, designed using the planning tools, might interfere with students' progress through the curriculum standards. Therefore, the mentor requested that Katie use the same PowerPoint lectures he created in previous years so that he knew her students would be exposed to the same required curriculum information set by the district. Katie said she felt constrained by her mentor's push for information delivery while planning her unit, noting his indifference to learning about the planning tools. Katie's mentor also declined to help her plan the volcano unit, citing a difference of teaching "techniques."

Rather than abandon the big idea-framed unit, Katie used the planning tools to create a unit focused on constructing an explanatory model of volcanic eruptions. She chose the frequency of volcanic eruptions as a puzzling phenomenon, selecting Mt. Kilauea (constantly erupts) and Mt. St. Helens (rarely erupts) as processes for students to explain. Katie selected this phenomenon for two reasons. First, the class had just completed a unit on plate tectonics, and she hoped that her students would draw on their work and ideas from the past two weeks to make sense of volcanoes. Second, Katie noted that Mt. St. Helens is within driving range of her school, and Mt. Rainier is visible from her classroom window. When prompted by an ambitious planning tool to explain her phenomenon selection, Katie wrote, "We live in [a] volcanically rich region, whose landscape is a result of volcanic activity". Katie stated the explanatory goals for students were to "understand how some volcanoes are made (plate subduction and hot spots), the importance of silica and viscosity of magma, and how pressure builds up, or does not, in certain volcanoes". Katie planned for her students to use ideas from the volcanic unit as part of their summative assessment to explain how Mt. Rainier might erupt. 
After Katie's initial lesson, she noted that her students expressed interest in the actual moment of volcanic eruptions themselves, not how they erupt over time. Therefore, Katie used the planning tools to recast her big idea to focus on the actual moment of volcanic eruptions. In another lesson, Katie heard students discuss the internal volcanic pressure of magma pushing on rock as an important piece of the causal explanation. Katie realized, however, that she did not include "pressure" in her own causal explanation for volcanic eruptions. Katie subsequently recast the big idea, adding pressure to her own explanatory story. In addition to recasting the big idea using the planning tools, Katie, when replaying students' conversations about pressure using questions from the planning tools, realized that she needed to add pressure activities to her unit to address students' emerging science ideas. Therefore, she put two new activities (carbon dioxide in a bottle and blasting sugar cube with air) in her unit, and decided to alter her expectations for students' final summative assessment to include "pressure."

While Katie's use of the planning tools influenced her immediate decision-making about her current unit, she also engaged in alternative and projective reasoning, considering her unit instruction in contexts with different affordances and constraints. Katie's alternative reasoning focused on the "time constraints" placed on her by the curriculum, in addition to her mentor teacher's reminders to keep pace with curriculum. In the planning tools, Katie wrote about other pieces of the causal explanation she wanted students to include (i.e., relationship between ash and lava; relationship between type of rock and amount of pressure), and sense-making conversations she wanted to facilitate with students, but could not because of time constraints. Katie's projective reasoning highlighted her desire to help students make better connections between pieces of the volcanic eruption causal explanation-such as how pressure and ash in an explosion are related. She also wrote that she spent too much time focusing on curriculum topics that were tangentially related to the causal explanation of a volcanic eruption (such as silica and lava viscosity), noting that students struggled to include these curriculum topics in their final explanations.

However, Katie's mentor teacher applied both explicit and tacit pressure for her to keep pace with the school curriculum, and as her unit progressed, Katie's resistance to his pedagogical expectations diminished. In particular, Katie's last class reflected the tension between her ambitious vision around helping students make connections between science ideas and the contextual expectations pressuring her to keep the pace of the curriculum. Frequently in this lesson, Katie added curricular and canonical facts onto students' statements to ensure that she covered the necessary information, while still expecting them to construct a causal explanation for volcanic eruptions. 
For example, during one sense-making discussion, Katie asked a student about the importance of pressure inside the volcano, and the student responded, "Their [volcano] gas is under pressure so when it's opening or something the gas tries to get out." Katie revoiced the answer but added a piece of information not initially offered by the student, "So they both have gas under pressure that is trying to get out, so when they erupt, the pressure causes the rock to burst and the change in pressure causes the magma to go with it" (observation notes). Katie's purposeful injection of content to expand a student's answer both mirrored a pedagogical move used by her mentor teacher, and was also reflective of her ambitious vision to help students connect science ideas. By the end of her unit, Katie's instruction was not antithetical to her big idea, her ambitious vision, or her mentor's preferred instructional strategies, but did not reflect her planning using the ambitious tools.

Robert's unit. Like Katie, Robert's mentor informed him that his unit needed to "cover" particular curriculum standards. In his case, enzyme structure and function. While Robert felt confident in his understanding of enzymes since he held a biology degree, he had never taught about enzymes prior to this unit, and was grateful his mentor gave him old PowerPoint presentations as a starting point for planning. While Robert wanted to plan with his mentor using the planning tools, he noted, "It [was] really different than what [my mentor] does and what [was] in [his] comfort zone" (final interview). Ultimately, Robert's mentor teacher told him to plan his unit alone because, like Katie's mentor, he did not have the time to understand the ambitious "technique" of teaching (final interview).

Robert's initial use of the planning tools reflected his vision of ambitious instruction, and focused on creating a collaborative student community in which students felt both connected to the science topics and "safe" to share ideas. He decided to situate enzymes in the larger context of digestion, asking students to theorize about why some people are lactose intolerant. He explained in his initial planning tools,

although the district wants us to focus primarily on proteins/enzymes themselves, I think studying them in the context of an actual process (breaking down lactose) will help kids understand their importance... I'm hoping that by using a common condition, that most kids should have heard of, then they will be more interested in learning about why people can't drink milk or eat dairy products.

Robert planned to engage students in a conversation about this phenomenon in order to include as many students as possible, facilitating the construction of a classroom community. 
After his first lesson, however, Robert's mentor teacher told him that their students had too many "gaps" in their knowledge of digestion, and therefore would not be able to connect the required curriculum topic-enzymes-to the big idea (observation debrief). Deciding that students' "gaps" were "too big to fill" during the unit, but still wanting to make the topic of enzymes accessible to all students, Robert recast his big idea to focus on explaining an activity (boiling lactase) found in the curriculum. Unlike Katie who increased the intellectual rigor of her unit, Robert decreased the rigor by reducing his expectations for students' intellectual work. I also saw evidence of Robert's reduced expectations when he replayed his lessons. Rather than have students learn about enzymes by focusing on lactose intolerance, Robert decided to highlight the four characteristics of enzymes promoted by the curriculum that he initially noted did not contextualize enzymes for students. In addition, he withdrew sense-making activities from the unit about digestion, replacing them with tasks that focused on enzyme characteristics, such as a computer simulation of the "lock and key" enzyme activation process, and using PowerPoint lectures created by his mentor teacher for classes taught in previous years.

While Robert's pedagogical reasoning processes of recasting and replaying illustrated his enactment of instruction aimed to deliver information to students, his alternative and projective reasoning in the planning tools indicated different thinking. Robert, like Katie, discussed a lack of time as a major influence on his decision-making. In the planning tools, Robert wrote that he wanted to help students consider why some enzymes work in stomach acid and others do not, and that he wanted students to explain relationships between structure and function. However, Robert stated that he was unable to "take the unit in that direction" after his mentor's statements about the students' lack of understanding and the time constraints that emerged from "taking too long for sense-making activities" (planning tools and final interview).

Like Katie, Robert started compromising his instruction after the first lesson, anticipating emerging conflicts if he did not align his instruction with his mentor and school's pedagogical expectations. For example, Robert found a computer simulation of enzyme function that he wanted students to use as a resource when explaining the lactase lab. He then developed a sense-making activity in the planning tools for students to discuss their emerging science ideas. However, Robert's mentor told him that he only had one more day for his unit, and that he was only allowed to sign out a class set of computers for one day. Rather than ask for an extra day for instruction, Robert recalled, 
one idea that [my mentor] had proposed is that I sit up in front of the class and I go through this simulation as a large group discussion. I didn't want to do that because I don't think the kids would have taken much out of it....I would prefer the kids to talk about it in the small group setting. So in order to have me be able to have the laptops, I removed the making sense activity of the lactase lab, which in the long run was probably a mistake. (final interview)

Even though Robert planned the sense-making activity in the planning tools using the computer simulation as a resource, he reduced the intellectual rigor of his unit because he did not deflect the pedagogical expectations of his school and mentor teacher.

Amber's unit. Unlike Katie and Robert's school context, Amber's school focused extensively on increasing students' standardized test scores. Therefore, Amber's mentor teacher asked her to get evolution "done" in the nine days before a holiday break in order to maintain the content "coverage pace" set by the department (final interview). In addition, Amber's mentor did not provide any lesson plans or other resources to her as a place to start planning her unit. This lack of material resources was not surprising to Amber, as she told us that her mentor teacher "doesn't plan. He uses kind of what he has used throughout the years and he will come in usually five minutes before class starts and just start delivering instruction" (final interview). Like Katie and Robert, Amber's mentor teacher also asked her to plan alone, claiming that she needed practice working in the "solitude of full-time teaching" (final interview).

Amber, like Katie and Robert, wanted to provide a context for natural selection by framing her unit around the phenomenon of the genotypic causes of the fennec fox's phenotypic appearance. The organism selection was purposeful, as Amber noted, "Many of my students come from both Northern and Sub-Saharan Africa and would have seen this fox before" (planning tool). Amber initially planned for students to compare the fennec fox to red foxes living in their urban environment, so they could analyze how natural selection operates on similar animals in different ecosystems. Amber's ambitious vision around scaffolding students' epistemic reasoning also informed her big idea construction. She planned for students to construct an explanation by making sense of data they collected from activities, not just copying notes from a lecture-a routine instructional strategy used by her mentor teacher.

I observed that Amber used the planning tools slightly differently than Katie and Robert. While the latter two anticipated students' interests and ideas while guessing at their partial understandings and ways of talking about science, Amber reasoned with her evolving content knowledge, which developed through multiple daily interactions 
with students in and out of the classroom. For example, after initially writing some questions to elicit students' ideas during the first lesson, Amber "picked a student and tried to think about how they think and tried to prepare questions based on how they think. I [tried] to think about what they might say to my questions and then what my response could be" (final interview). Using the planning tools, Amber engaged in an imagined rehearsal of students' responses to her questions, which she subsequently asked while teaching the first class. During her initial lesson, therefore, Amber was primed to notice and find value in a wide range of students' ideas.

Specifically, during her first lesson, Amber heard students discuss two ideas she realized were missing from her own causal explanation of natural selection: the long time intervals in which natural selection operates, and the importance of sexual reproduction (possible genetic outcomes and the actual genotypes of offspring) for mammal evolution. Amber revised her own explanation using the planning tools, and recast the big idea to include time and reproduction. Later in the unit, Amber heard students invoke a Lamarckian explanation for fennec fox coloration (i.e., the fox can change colors to match its habitat, and can pass that color change gene to offspring). She therefore again recast her big idea, this time focusing on competing evolution models for fennec fox coloration that students constructed: Lamarck's single generation change and Darwin's gradual model.

Like Katie and Robert, Amber only engaged in alternative and projective reasoning in the planning tools. Amber also claimed a "time constraint" as the most immediate influence on her decision-making, hoping for students to have more time for sensemaking discussions. In addition, she reasoned in the planning tools that given more time for sense-making, her current students likely would have discussed relationships between genetic mutations and "abnormal" phenotypic traits-the next piece of the evolution causal explanation that Amber planned to teach but could not longer do so. Amber's projective reasoning focused on her frustration with her school and mentor's expectations for student learning. In the planning tools, Amber wrote that in the future, she will "bring DNA in earlier because students were searching for that idea when trying to explain natural selection." In addition, she planned to design activities before the next school year to illuminate and address her imagined future students' partial understandings of what she had become aware of during conversations and classroom discussions with her current students.

While Amber's unit time was constrained like Katie and Robert, her instruction aligned most closely with her ambitious vision and pedagogical reasoning. For example, while Katie and Robert began to establish themselves as the gatekeepers of 
information, Amber positioned students' emerging theories about natural selection as central to solving a conceptual puzzle that surfaced during a class discussion. After hearing student conversations in which they rallied ideas from Lamarck's evolution model that the fox could turn darker during its lifetime and pass that trait on to offspring, Amber asked students to explain the fennec fox's unique coloration by comparing Lamarck and Darwin's competing models of evolution. However, Amber did not rely on her mentor's PowerPoint presentations, nor did she tack on canonical information to students' ideas. Instead, she facilitated small-group and whole-class discussions in which students used evidence from activities and their own growing understanding of evolution to construct a final causal explanation.

Like Katie and Robert, Amber's mentor teacher cut short her ambitious planning and teaching by insisting that she end her unit sooner than she anticipated. In addition, Amber's last lesson, in which students rallied evidence to support either a Lamarckian or Darwinian explanation for fennec fox coloration, lasted only 40 minutes because of an unexpected school-wide assembly. Though Amber requested more time for her students to complete their explanations, her mentor told her that her unit was over. Despite these contextual constraints and potential pedagogical roadblocks, Amber's goal as a first-year teacher remained the same: enact ambitious instruction she felt would benefit students' intellectual work around a big idea (final interview).

\section{Understanding the Novices' Tool Use and Instruction}

To explain why the three participants used the planning tools and taught in particular ways, I offer two assertions: The tools provided an ambient press on participants for ambitious instruction, and the participants developed an ambitious vision of instruction using the tools that carried into their student teaching experiences.

The "ambient press" of university planning tools. While some literature suggests that the contextual pressure to conform to particular norms overwhelms beginning teachers' vision and practice (see Gainsburg, 2012; Hewson, Tabachnick, Zeichner, \& Lemberger, 1999), I argue that the planning tools provided participants with an instantly accessible alternative vision of practice to counter the expectations for information delivery embedded in their school. The planning tools acted as boundary objects, codifying and transporting ambitious practices from the university-based methods class context to the school setting. Thus the planning tools provided an "ambient press" on the participants to plan differently than they might otherwise, given their school's norms and expectations for instruction. 
One key feature of the participants' learning was the use of students' emerging science ideas as resources to inform instructional decisions. Rather than rely solely on the school's mentor teacher and curriculum to direct their actions, the participants adapted their immediate planning and imagined future instruction based on what they learned about student thinking. According to some literature, this learning and reasoning is difficult for, and rare among, beginning teachers (see Bianchini \& Cavazos, 2007; Cohen, 2008; Warren et al., 2001). However, I saw that as the participants planned, taught, and reflected on their lessons using the tools, they continually learned from practice by considering students' theories, partial understandings, experiences, and discourses. Subsequently, the participants reconsidered their assigned science topic in ways that did not occur to them before interacting with their particular students. Such interactions prompted them to revise what counted as a gapless explanation, and what pieces to add or take away from the big idea, depending on what they learned from their students.

By providing an "ambient press" for the participants to engage in the four pedagogical reasoning processes centered on student thinking, the planning tools did not act as a point of communication between the participants and their mentor teachers. Rather, the tools tacitly prompted the participants to subvert the institutional messages that upheld a curriculum and textbook as embodiments of knowledge for effective instruction. This process was risky for the participants for two reasons. First, continually reframing the big idea of the unit led to tensions among the mentor teachers who did not share the participants' vision of ambitious instruction. Second, by continually leveraging their developing ambitious instruction and reshaping their unit around student thinking, the participants destabilized what would normally be the bedrock of instruction-the scope, sequence, and pace of the curriculum. This high level of professional risk might help to explain why the participants' pedagogical reasoning reflected elements of ambitious instruction only in the planning tools.

\section{Participants' Ambitious Vision of Practice}

While the planning tools provided an "ambient press" for the participants to learn in particular ways, I recognize how a tool is used depends on the individual or group using it (Cohen, Raudenbush, \& Ball, 2002; Engeström, 2004). I propose that the participants' response to the planning tools' "ambient press" for ambitious instruction occurred in part because their vision of ambitious instruction acted as a filter for what they paid attention to when planning, instructing, and reflecting. By developing a vision of instruction that foregrounded student thinking and collaboration-key aspects of ambitious teaching - I observed the participants continually planned instructional 
opportunities in which they could learn more about students' ideas. The planning tools, then, provided scaffolding that allowed the participants to use student thinking as a resource for their own learning. I posit that if the participants did not develop a vision of ambitious instruction that focused on students' thinking and collaboration, they likely would have used the tools differently than they demonstrated in this study, perhaps even dismissing students' ideas as irrelevant (Cohen et al., 2002). Therefore, the participants' vision of ambitious instruction mediated what they attended to in their teaching, what they saw as opportunities or problems in their school context, and how they used the planning tools to learn from these daily episodes.

In addition to mediating learning, the participants' vision of ambitious instruction worked to deflect some, if not all, of their school's multiple pushes for information delivery as the primary aim of instruction. While all three participants in this study valued student thinking and collaboration, they compromised their instruction to varying degrees as they made sense of the tacit and/or explicit constraints placed on them by their school-based mentor teachers (Gainsburg, 2012). Katie and Robert, while focused on student thinking and learning, prioritized different aspects of learningconnecting ideas for students and building collaborative classrooms - than Amber did when planning, instructing, and reflecting. Amber, whose ambitious vision focused on students' epistemic reasoning and participation in science practices, consistently deflected her school's instructional expectations when making various pedagogical decisions and when teaching lessons (see Thompson et al., 2013). Such subtle differences in their visions of instruction might have resulted in disparate theories of action-that is, Katie and Robert's compromises of instruction to either "cram" ideas into students' heads or reduce the intellectual expectations for student learning.

\section{Concluding Thoughts for Teacher Education}

At the outset of this article, I aimed to test a hypothesis that tools for ambitious planning could provide more coherence between preservice teachers' initial preparation contexts and their school-based instructional experiences. While I see evidence that the participants learned from their attempts to enact ambitious practice by using the planning tools, I am keenly aware that all three participants compromised their actual instruction to some degree because of the tensions that arose as they made sense of their school's pedagogical expectations. These instructional compromises were a successful professional survival strategy for the participants, but the compromises also meant that the participants' students did not immediately benefit from their teacher's 
learning in the planning tools. This gap between teacher learning evidenced in the planning tools and how their instructional decisions benefit students' science learning reflects the lack of support the participants received to try out ambitious instruction.

Given the lack of a common vision of teaching found in the tools and in the school context, there is a need for better coherence across teacher preparation contexts-we need agreement and support about the valued practices, instructional expectations, and learning trajectories for beginning teachers. One form of coherence begins with teacher educators - if we want to provide tools to beginning teachers to enact ambitious instruction, we must also provide supports for the novices as they attempt to use the tools over time rather than watch tensions emerge between beginner and mentor teachers.

I also acknowledge that these three participants provided a unique opportunity for cross-case analysis because they all developed a vision of ambitious instruction. I recognize that not all preservice science teachers have support to develop a vision of ambitious instruction during their teacher preparation program. Nor do they have support to use planning tools in ways that align with the design of the tools. I therefore have begun, as a teacher educator, to study the supports beginning teachers need to construct and maintain a vision of ambitious instruction. An important feature of this development is the school-based mentor teacher. Since I saw that mentor teachers have a strong influence on what beginning teachers learn and do during instruction, I want to better understand how to support the mentor teachers' learning and development of a vision of ambitious instruction. 


\section{References}

Ball, D., Sleep, L., Boerst, T., \& Bass, H. (2009). Combining the development of practice and the practice of development in teacher education. The Elementary School Journal, 109(5), 458-474.

Bianchini, J. A., \& Cavazos, L. M. (2007). Learning from students, inquiry into practice, and participation in professional communities: Beginning teachers' uneven progress towards equitable science teaching. Journal of Research in Science Teaching, 44(4), 586-612.

Cobb, P., Zhao, Q., \& Dean, C. (2009). Conducting design experiments to support teachers' learning: A reflection from the field. Journal of the Learning Sciences, 18(2), 165-199.

Cohen, D. K. (2008). Knowledge and teaching. Oxford Review of Education, 34(3), 357-378.

Cohen, D. K., Raudenbush, S. W., \& Ball, D. (2002). Resources, instruction, and research. Evidence matters: Randomized trials in education research (ED. BY F. Mosteller and R. Boruch., pp. 80-119). Washington, D. C.: Brookings Institution Press.

Duschl, R. (2008). Science education in threepart harmony: Balancing conceptual, epistemic, and social learning goals. Review of Research in Science Education, 32, 268-291.

Engeström, Y. (2004). The new generation of expertise: Seven theses. In A. Fuller, A. Munro, and H. Rainbird (Eds.), Workplace learning in context (pp. 145-165). New York: Routledge.

Gainsburg, J. (2012). Why new mathematics teachers do or don't use practices emphasized in their credential program. Journal of Mathematics Teacher Education, 15(5), 359-379.

Grossman, P., Hammerness, K., \& McDonald, M. (2009). Redefining teaching, re-imagining teacher education. Teachers and Teaching: Theory and Practice, 15(2), 273-289.

Grossman, P., \& McDonald, M. (2008). Back to the future: Directions for research in teaching and teacher education. American Educational Research Journal, 45(1), 184-205.
Hewson, P. W., Tabachnick, B. R., Zeichner, K. M., \& Lemberger, J. (1999). Educating prospective teachers of biology: Findings, limitations, and recommendations. Science Education, 83, 373-384.

Horn, I. S. (2010). Teaching replays, teaching rehearsals, and re-visions of practice: Learning from colleagues in a mathematics teacher community. Teachers College Record, 112(1), 225-259.

Kazemi, E., Franke, M., \& Lampert, M. (2009). Developing pedagogies in teacher education to support novice teachers' ability to enact ambitious instruction. In R. Hunter, B. Bicknell, \& T. Burgess (Eds.), Crossing divides: Proceedings of the 32nd annual conference of the Mathematics Education Research Group of Australiasia (Vol. 1, pp. 11-21). Palmerston North, NZ: MERGA.

Kennedy, M. (2010). Attribution error and the quest for teacher quality. Educational Researcher, 39(8), 591-598.

Lampert, M., \& Graziani, F. (2009). Instructional activities as a tool for teachers' and teacher educators' learning. The Elementary School Journal, 109(5), 491-509.

Penuel, W. R., \& Gallagher, L. P. (2009). Preparing teachers to design instruction for deep understanding in middle school earth science. The Journal of the Learning Sciences, 18, 461-508.

Putnam, R., \& Borko, H. (2000). What do new views of knowledge and thinking have to say about research on teacher learning? Educational Researcher, 29(1), 4-15.

Sykes, G., Bird, T., \& Kennedy, M. (2010). Teacher education: Its problems and some prospects. Journal of Teacher Education, 61(5), 464-476.

Thompson, J., Windschitl, M., \& Braaten, M. (2013). Developing a theory of ambitious early-career teacher practice. American Educational Research Journal, 50(3), 574-615.

Warren, B., Ballenger, C., Ogonowski, M., Rosebery, A., \& Hudicourt-Barnes, J. (2001). Rethinking diversity in learning science: The logic of everyday sense-making. Journal of Research in Science Teaching, 38(5), 529-552. 
Warren, B., \& Rosebery, A. (1995). Equity in the future tense: Redefining relationships among teachers, students, and science in linguistic minority classrooms, In W. Secada, E. Fennema, \& L. Adajian, (Eds.), New Directions for Equity in Mathematics Education, 289-328. New York: Cambridge University Press.

Wenger, E. (1998). Communities of practice: Learning, meaning, and identity. Cambridge: Cambridge University Press.

Wilson, S. M., \& Berne, J. (1999). Teacher learning and the acquisition of professional knowledge: An examination of research on contemporary professional development. Review of Research in Education, 24, 173-209.
Windschitl, M., Thompson, J., Braaten, M., \& Stroupe, D. (2012). Proposing a core set of instructional practices and tools for teachers of science. Science Education, 96(5), 878-903.

Zeichner, K. (2010). Rethinking the connections between campus courses and field experiences in college- and university-based teacher education. Journal of Teacher Education, 61(1-2), 89-99.

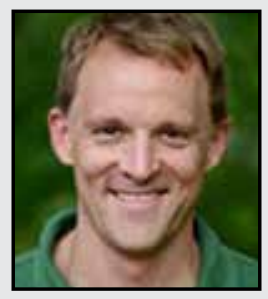

David Stroupe is an Assistant Professor of Teacher Education at Michigan State University. He has three overlapping areas of research interests anchored around ambitious teaching practice. First, he frames classrooms as science practice communities. Using lenses from Science, Technology, and Society (STS) and the History and Philosophy of Science (HPS), he examines how teachers and students negotiate power, knowledge, and epistemic agency. Second, he examines how beginning teachers learn from practice in and across their varied contexts. Third, he studies how teacher preparation programs can provide support and opportunities for beginning teachers to learn from practice. David has a background in biology and taught secondary life science for four years.

LINK TO:

http://michiganstate.academia.edu/DavidStroupe http://tools4teachingscience.org 